\title{
Science Student Teachers' Independence as New Adaptation of Distance in Basic Biology Practicums
}

\author{
Parmin $^{1 *}$, Erna Noor Savitri ${ }^{1}$, Endah Fitriani Rahayu ${ }^{1}$ \\ ${ }^{1}$ Faculty of Mathematics and Natural Science, Universitas Negeri Semarang, Indonesia.
}

DOI: $\underline{10.29303 / \text { jppipa.v7i4.947 }}$

\section{Article Info}

Received: September $5^{\text {th }}, 2021$

Revised: October $14^{\text {th }}, 2021$

Accepted: October 16 $6^{\text {th }}, 2021$

\begin{abstract}
The education process for science student teachers in Indonesia must continue, even in a pandemic situation with an unclear end. The research aims to find the most appropriate science practicum method during the Covid-19 pandemic for science student teachers. The method used in this research is mix-methods. The research design chosen by the researcher is the Pre-Experimental One-Group Pretest-Posttest Design. Participants in this study were 140 science student teachers who did distance practicum on basic biology practicum courses. Basic biology practicum is a practicum course that practices biological science, including respiration, photosynthesis, nutrient content of food, and pollutant testing. Based on gender, the participants were 62 male students and 78 female students. The value of $\mathrm{N}$-Gain $\mathrm{d}>0.58$ (moderate effect) means that practicum activities can be continued as a practicum solution during the pandemic. Student activities during a practicum at home apply new adaptations different from a practicum in the laboratory. Independence in preparing materials and tools, preparing worksheets, simplifying materials, and modifying tools is a new way for students. The study concludes that a new practicum method that utilizes the environment potential is a solution in the implementation of science practicums as a result of the Covid-19 pandemic in Indonesia. The environment can be explored to find resources that can be used as practicum materials and the manufacture of basic biology practicum tools.
\end{abstract}

Keywords: science practicum; local wisdom; independent project; covid-19; distance learning

Citation: Parmin, P., Savitri, E., \& Rahayu, E. (2021). Science Student Teachers' Independence as New Adaptation of Distance in Basic Biology Practicums. Jurnal Penelitian Pendidikan IPA, 7(4), 729-737. doi:https://doi.org/10.29303/jppipa.v7i4.947

\section{Introduction}

The laboratory cannot be used as a place for science practicum activities due to the Covid-19 pandemic. Learning is done completely online, so there is no direct meeting between student practitioners and lecturers. The education process for science student teachers in Indonesia must continue even in a pandemic situation. Life safety is a priority in the implementation of education so that practicum activities are carried out with online distance strategies. It is unclear when the Covid-19 will end while the teacher candidate education curriculum continues due to the limited student study period. Several problems were found since the implementation of the practicum at the beginning of the pandemic in Indonesia in early 2020. These problems are sure to also occur in most universities in the world. Fundamental problems include limited practicum materials, low students' independence in doing practicum, poor practicum results, and a low understanding of practicum results. Low understanding of science indicates ineffective learning activities (Melki et al., 2020; Gürsoy, 2021; Suyatman et al., 2021; Ramdani et al., 2021). The online distance practicum strategy is a real problem faced by many universities in Indonesia.

\footnotetext{
*Email: parmin@mail.unes.ac.id
} 
Practicum lectures must continue even though they are carried out from home by utilizing local wisdom in the students' living environment. Science learning resources that utilize local wisdom show that science is integrated with life (Savitri et al., 2021; Purnami et al., 2021). Indonesia is an agricultural country that has an abundant diversity of natural resources. These resources can be used as materials and even practicum tools for many topics, for example, vitamin test labs and testing processes that utilize natural ingredients. The materials are easy to find in the students' living environment. Practicums that utilize materials and tools available at home and in their environment are named practicum with local wisdom. The latest policy in the education curriculum for science student teachers in Indonesia requires that practicum is not just an integrated part of an administration course but as a means of fostering independent learning.

The existence of complicated practicum problems during the pandemic and the demands of practicum results as an independent student project requires the right practicum strategy. The scientific testing process is not limited by space because it can take advantage of local wisdom in the environment in certain or abnormal situations. The scientific process is in line with authentic scientific practicums that can be carried out both indoors and outdoors (Crippen et al., 2013; Han, 2019; Muris, 2020; Permanasari et al., 2021). Practicum on learning for adults emphasizes independent learning. Indicators of practicum work independence start from preparing practicum worksheets, preparing materials and tools, conducting experiments, finding solutions to problems and reporting results. Practicum must still be held in a pandemic situation. Adaptation in learning as a result of Covid-19 since 2020 requires skills in making teaching materials using information technology tools (Teras et al., 2020; Yang et al., 2020). Learning interactions during the Covid-19 pandemic occurred in online media (Galloway et al., 2020; Reiss et al., 2020). Distance practicum requires skills to use online learning. As the target of this research, science student teachers have become accustomed to using several online application programs such as ZOOM and Google Meet.

Distance practicum requires mastery on online application programs for discussion media of practicum results. The use of online devices is a form of adaptation of practicum activities due to the Covid-19 pandemic (Lockee et al., 2020). E-learning with discussion forums and quizzes to present material is effective for online learning (Adros \& Nina, 2018; Rahman et al., 2020). Practicum conducted through distance learning has challenges and obstacles that require new adaptations. Various learning difficulties were found in distance learning carried out during Covid-19, which required proper handling (Tzivinikou et al., 2020; Daniel, 2020). Tal et al. (2019) revealed a shift in educators' views in managing practicum. Initially, student-centered activities were limited to laboratories, then changed and expanded with outdoor practicums. The new adaptation of the science practicum is inevitable because the pandemic has no certainty when it will end while the educational process must continue.

Previous research studies confirm that practicum can be carried out outside the laboratory to optimize the environment for practicum. However, not all practicum topics can be done outside the laboratory. Some practicums must use special tools in the laboratory and cannot be replaced with other tools. The environment has biotic and abiotic resources. Environmental resources used for practice bring the practitioner closer to the object of scientific study (Carrier et al., 2013; Tsinajinie et al., 2020). Learning independence is the implementation of freedom in learning (Van et al., 2015). Practicum is not limited to proving and testing activities but must be developed into discovery activities (Robinson, 2013). Outdoor learning can foster natural collaboration through discovery activities (Angelstam et al., 2013). Testing materials from the environment carried out directly outdoor provides a contextual reinforcement of the scientific process (Degenkolb et al., 2019; Saraswati \& Mertayasa, 2020).

Analysis of various research findings regarding the implementation of practicum during the pandemic requires a method as a new form of adaptation because students still have to do practicum due to the ongoing Covid-19 pandemic. The Covid-19 pandemic is predicted to last long, especially in Indonesia, because its distribution is increasingly widespread. New practicum methods as an adaptive response are urgently needed. Hariyanti et al. (2020) explained that practicum in distance learning is not used to be done in Indonesia, so there are many obstacles in its implementation. If the various obstacles that have been described in the preliminary research of this research are not overcome, there would be a potential for the low quality of future science student teachers in Indonesia. Before the pandemic, students were accompanied by laboratory assistants to prepare tools, materials, and practicum processes. Students are forced to be independent in distance practicum (Zunaidah, 2020; Mila \& Randi, 2020). In the practicum, the practitioner refers to the prepared practicum guide. The existing guidelines are applied in normal conditions or activities in the laboratory. Applying the existing guidelines to practicum at home or distance is difficult because of limited materials and tools. One of the 
strengths of distance practicum is the observation activities carried out by students in mapping the potential in the environment that can be used as materials and tools for practicum.
The design of making science student teachers independent as a new adaptation of distance practicum implementation is shown in Figure 1.

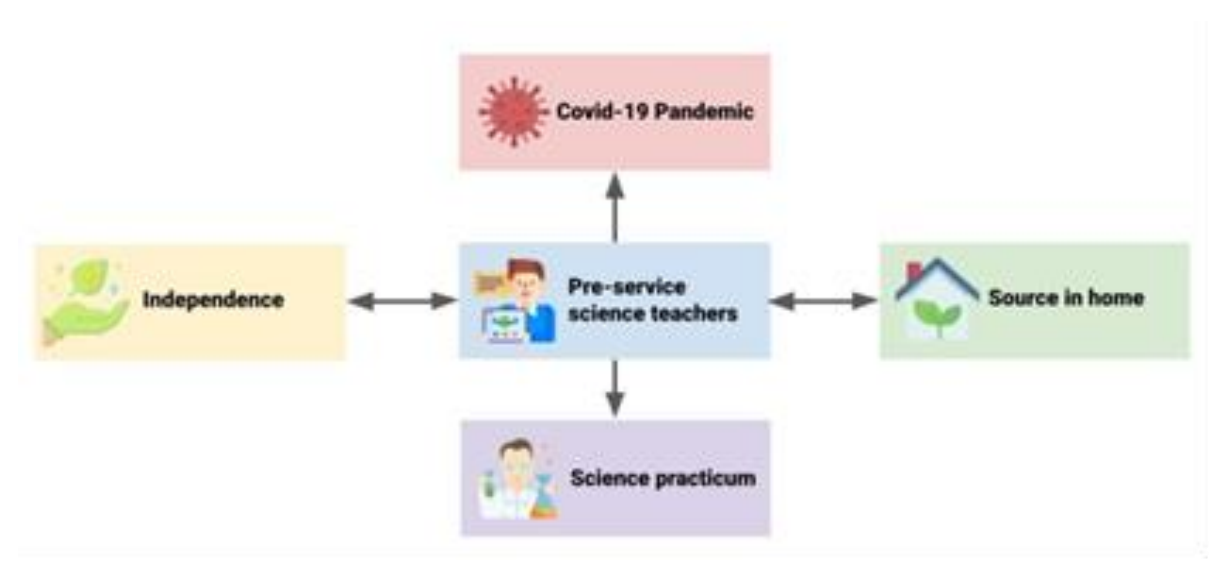

Figure 1. The Design of New Adaptation of Distance Practicum Implementation

Practicum is a basic competency that science student teachers must possess. According to Dede (2018), the main competence of prospective teacher graduates is able and skilled in experiments. Students' practicum is not limited to concept application activities but also finding concepts and developing a product. Suryawati (2018) explained that practicum competence is determined by the intensity of students in doing practicums. During a pandemic, students must continue to do practicums with new adaptations through innovative methods. Lecturers in practicum courses need adjustments to new methods that help students carry out practicums during the pandemic. This research aims to find the most appropriate science practicum method during the Covid-19 pandemic for science student teachers. The suitable method of science practicum is determined from (1) the implementation of an effective practicum that utilizes materials and tools from local wisdom, (2) full independence of student teachers in practicum activities, and (3) student teachers' level of understanding of the practicum results.

\section{Method}

The method used in this research is mix-methods (Cresswell, 2016). Mix-methods are used because comprehensive facts are needed to obtain a new adaptation method for remote practicum, so various quantitative and qualitative data collection tools are needed. The opinions of the practicum students in this study were obtained through interviews and measurements with test instruments. The research target was taken using the purposive sampling technique. The number of participants in this research was 140 prospective science student teachers who did remote practicum on basic biology practicum courses. Based on gender, the participants were 62 male students and 78 female students. Through online documents, research participants have been confirmed to do practicum from home.

The research design is presented in Figure 2.

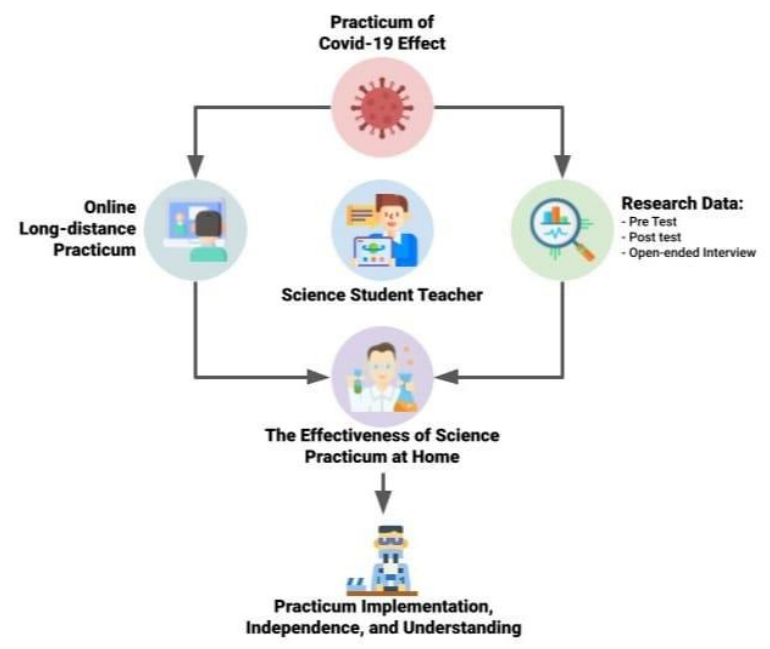

Figure 2. Research Design

Quantitative data were obtained from pretest and posttest on practicum material. The research design chosen by the researcher is the Pre-Experimental One-Group Pretest-Posttest Design. The researcher chose this design because there are still many external variables that affect the dependent variable in the research that is difficult to control. The design in the experimental class was from the comparison of pretest and posttest scores without being compared to the control class. The aspects compared are independent 
variables before treatment (pretest) and after treatment (posttest). The independent variable of this research is the practicum independence of the science student teachers, while the control variable is the practicum activities by students. The value of students' cognitive learning outcomes after practicum activities was compared with the pretest and posttest values with the normalized gain test (N-Gain) to compare the actual gain score with the maximum gain score. The calculation of the normalized gain score (N-Gain) refers to Cohen et al. (2007).

This research also explores the data from the pretest and posttest results by analyzing closed-ended questionnaires. Qualitative data is from information that combines closed and open-ended information collected by researchers through interviews with participants. Each participant answered using their language in order to obtain accurate information. This research adds qualitative data collected through analysis of students' practicum reports. The pretest and posttest instruments in this research were in the form of 20 multiple-choice items to measure students' knowledge of the basic biology material for practicum. There are four answer choices in A, B, C, and D.

Items were analyzed using the formula for the level of difficulty. The results obtained from the number of students who answered correctly divided by the number of students obtained a difficulty level value of $<0.30$ which means the question is in the difficult category. The use of questions that have a high level of difficulty, which is suitable for the needs of students in higher education, was adopted from Purwanto (2011). After the pretest and posttest data were obtained, the data were analyzed by performing statistical tests at a significance level of $5 \%$. The requirements that must be met first are normality and homogeneity tests. If the data is normally distributed, then parametric statistical tests are used, but if they are not normally distributed, non-parametric statistical tests are used. The normality test was conducted to determine whether the data were normally distributed or not. The normality of the data was tested using Kolmogorov-Smirnov on SPSS version 23 with a significance level of $5 \%$.

Interview data were collected with research participants using an open-ended instrument. The instrument consists of 8 questions to reveal students' independence in four topics, each in two questions: (1) compiling a practicum worksheet, (2) identifying the need for tools and materials, (3) preparing tools and materials, and (4) place do the practicum. The interview instrument refers to Bungin (2008) through the stages of making grids, compiling instruments, being validated by experts before using, and being tested on students in other classes. The results of expert validation stated that the instrument was feasible to use. Students in the other class can understand the instrument being tested. Students were interviewed online by the research team individually to not know other students' answers. Interviews are the data that will determine the discovery of new adaptation methods in this study.

\section{Result and Discussion}

The normality test obtained a calculated sig value of $0.46 \geq 0.06$ sig table, which means the data was normally distributed. Based on the normality test, the data is normally distributed. The data group comes from a population with the same variance (homogeneous). The normality test results showed that the value of the distribution of the data on the research target was normal. The value of N-Gain $\mathrm{d}>0.58$ (medium effect) means the practicum activities at home are successful, and its effectiveness has been proven from a review of the cognitive understanding of student teachers. Although there were more women in the research target class, no significant difference was found between the practicum results conducted by women and men. This study did not explore the gender factor.

The data on the pretest and post-test scores are presented in Figure 3.

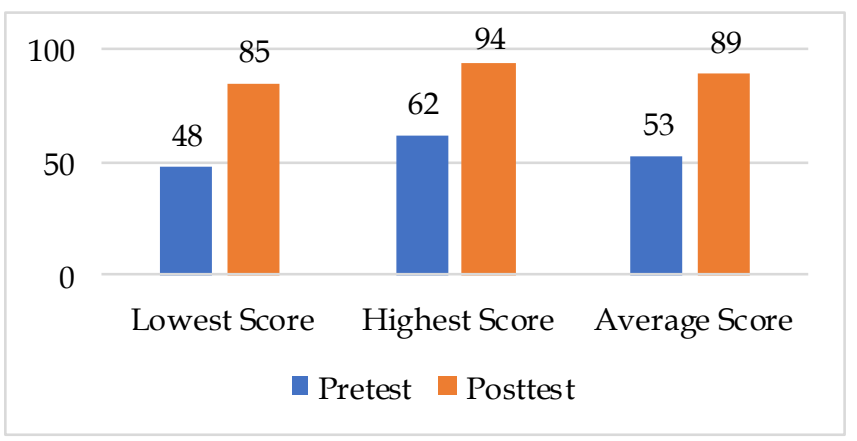

Figure 3. The Comparison of Pretest and Posttest Scores

The $\mathrm{Y}$-axis in the table is a range of values from 0 to 100 to present the values obtained in the pretest and posttest. The analysis of the N-Gain value has a moderate effect on increasing research targets' concept understanding, with an increase in the average score from 53 (pretest) to 89 (posttest). This research did not analyze research targets' patterns of test answers in depth. N-Gain is only used to confirm how much the research targets' concept understanding increases before and after the practicum. There is no special and different treatment between research targets, meaning that there is no control class and experimental class. After the score of concept knowledge was analyzed, the practicum report score was obtained from 140 research targets with an average score of 83 . These results 
indicate that the research target can make a good practicum report. The research target is 4th-semester students who had practicum experience in the laboratory for one year before the pandemic period so that they certainly have experience in writing practicum reports. Online assistance is also provided by lecturers when students prepare reports.
The primary data in this research were a combination of closed and open-ended interviews. The results of this interview become information that will determine the success of the implementation of the practicum as a new adaptation of online practicum at home. The results of interviews with closed-ended answer choices, science student teachers who answered "agree" from 140 participants, are presented in Figure 4.

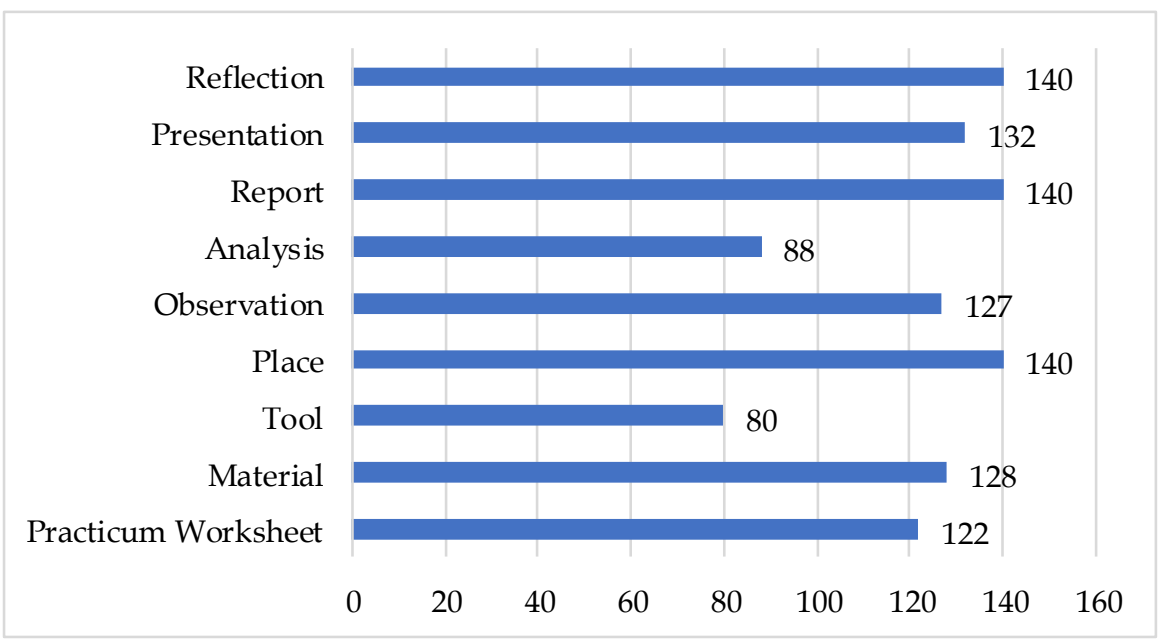

Figure 4. Interview Results from Closed-ended Answer Choices

The interview data in Figure 4 was confirmed by $20 \%$ of the respondents or 35 participants taken randomly from 140 participants. Interviews are closed, students do not know each other's responses or answers. The results of this closed interview will determine the information on the implementation of the practicum at home. The results of the interviews are presented in Table 1.

Table 1. The Results of Open Interview with Science Student Teachers

\begin{tabular}{|c|c|c|}
\hline Question & Respondents' Answer & Conclusion \\
\hline $\begin{array}{l}\text { How do you identify practicum } \\
\text { resources in the environment around } \\
\text { your home? }\end{array}$ & $\begin{array}{l}\text { I prepared the observation sheet first, } \\
\text { then observed the environment around } \\
\text { the house and asked the people around. }\end{array}$ & $\begin{array}{l}\text { Students explore practicum resources in } \\
\text { the environment around the house in a } \\
\text { planned way. }\end{array}$ \\
\hline $\begin{array}{l}\text { What criteria do you use in determining } \\
\text { the practicum tools from the } \\
\text { environment around the house? }\end{array}$ & $\begin{array}{l}\text { I analyze actual practicum tools to be } \\
\text { modified into simple practicum tools. }\end{array}$ & $\begin{array}{l}\text { Students modify simple practicum tools } \\
\text { using available materials }\end{array}$ \\
\hline $\begin{array}{l}\text { How do you compile a practicum } \\
\text { worksheet? }\end{array}$ & $\begin{array}{l}\text { I analyze practicum worksheets from } \\
\text { various sources to simplify according to } \\
\text { available materials and tools. }\end{array}$ & Students simplify practicum worksheets \\
\hline $\begin{array}{l}\text { What considerations do you use in } \\
\text { determining the location around the } \\
\text { house as a place for practicum? }\end{array}$ & $\begin{array}{l}\text { Lighting, space, easy access for } \\
\text { observation activities, and out of reach } \\
\text { of children }\end{array}$ & $\begin{array}{l}\text { A room with sufficient lighting and } \\
\text { space }\end{array}$ \\
\hline $\begin{array}{l}\text { How do you prepare before presenting } \\
\text { the practicum results online? }\end{array}$ & $\begin{array}{l}\text { I check the internet connection, prepare } \\
\text { presentation materials, and choose a } \\
\text { convenient location at home }\end{array}$ & $\begin{array}{l}\text { Online presentation with a good internet } \\
\text { connection }\end{array}$ \\
\hline
\end{tabular}


The activities of student teachers during the practicum at home apply a new adaptation that is different from the practicum activities in the laboratory. Independence in preparing materials and tools, preparing worksheets, simplifying materials, and

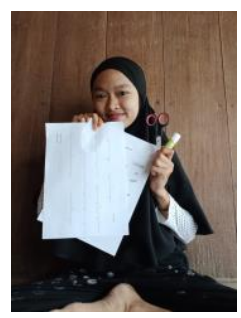

(a)

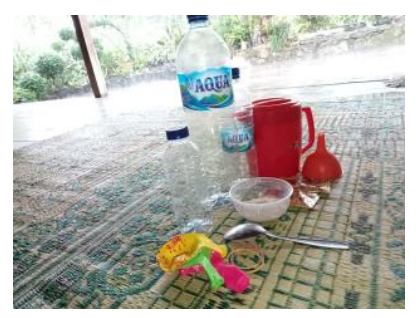

(b)

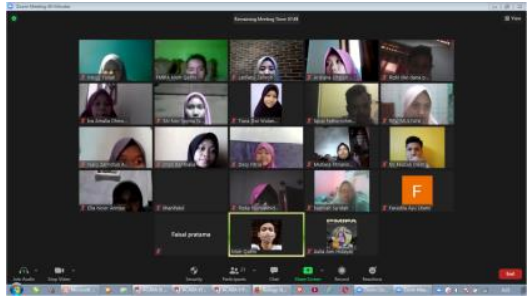

(c)

Figure 5. (a) Student-made practicum worksheets; (b) Practicum on the terrace; (c) Online presentation of practicum results

Figure 5 (a) shows a science student teacher showing a practicum worksheet. Students themselves make the practicum worksheets. In Figure (b), students prepare practicum materials and tools from the environment and around the house. Students themselves collect practicum materials and tools. In Figure (c), students do an online meeting with lecturers and classmates to present and discuss the practicum results. Basic biology practicum is conducted with four topics: respiration, photosynthesis, nutrient content of food, and pollutant test.

Students independently identify the potential of the environment around their residence by using observation instruments. The preparation of observation instruments shows the seriousness of students to find practicum materials. The process of identifying the source of the practicum material is done by going directly to the surrounding environment and asking people around who know the practicum material being sought. The activity of finding the source of the practicum material itself is not carried out during the practicum in the laboratory. Students have started to make new adaptations independently by collecting information, searching, and taking practicum materials from nature. Students realize that they cannot do practicum without finding the required materials. Learning science during the COVID-19 pandemic requires new ways that dare to break out of old habits before the pandemic (Suoranta, 2020; Erduran, 2020; Abdullah et al., 2021). Students may not be able to search and find practicum materials if they do not understand the knowledge to be practiced. The skill to find practicum materials from the environment around where they live, encourages students to understand the knowledge practiced. After students find the materials, they must prepare the practicum tools needed.

Preparing practicum tools is more complicated than materials because students must have the skills to assemble or modify practicum tools. Students prefer to use used materials in the environment because they are cheaper and easy to obtain. Students may not be able to modify practicum tools if they do not understand the actual practicum tools. Modifying science practicum tools is needed if the existing practicum tools are limited or lacking (Khan, 2019). The skill to modify the tools by the students leads to the simplification of the original practicum tools. Practicing at home requires students to modify practicum tools, or the practicum cannot be carried out. The situation of compulsion encourages students to develop the ability to make simple practicum tools from materials that are easily found in nature.

When practicum in the laboratory, students usually prepare materials and tools based on existing practicum worksheets. Practicum worksheets are used as the basis for preparing materials, tools, and work procedures. However, habits in the laboratory cannot be applied when practicum at home. The way students work is the opposite of the usual procedure. After the students prepare the materials and tools, the students compile a worksheet used as a reference for work procedures. Without clear materials and tools, the practicum activities in the worksheet cannot be formulated. Safaruddin et al. (2020) stated that science practicum requires practicum worksheets that must be well understood by every practitioner. The practicum worksheets prepared by students are more straightforward than the ones in the laboratory. Students make worksheets by analyzing from various sources and then simplifying them according to available materials and tools.

The readiness of materials, tools, and practicum worksheets has proven to support the implementation of practicum at home. Students can prepare for the observation process freely by choosing their preferred practicum place. The selection of the practicum place considers the lighting, the space, easy access for observation activities, and being out of reach of 
children. Kang (2019), Tuan (2019), and Vilsmaier (2019) revealed that outdoor science learning is the right choice to get closer to original learning resources. Of course, not all practicum can be done outdoor. The topic of practicum conducted by students is basic biology practicum which has been considered to be carried out in nature. The practicum that cannot be done outside the laboratory is those that require modern tools that cannot be modified or replaced. This research opens insight that practicums can be carried out outside the laboratory even in pandemic conditions for practicum topics that do not require special equipment in the laboratory.

The value of N-Gain $d>0.58$ (moderate effect) means that practicum can be continued as a practicum solution during the pandemic. Students who are studying from home can still do the practicum. The research findings show that the results of practicum at home have a moderate effect on students' knowledge. This research is a solution to prepare science student teachers during the pandemic. Many students in Indonesia are not doing practicum during the pandemic. The new adaptation of the practicum during the pandemic as the research findings is expected to be widely applied in preparing teacher candidates, at least in Indonesia. It is unclear when the Covid-19 will end while science learning cannot be separated from practicum.

\section{Conclusion}

A new practicum method utilizing the environment potential is a solution in organizing science practicums due to the Covid-19 pandemic in Indonesia. The face-to-face practicum cannot be done, so learning methods must be created that encourage students' independence learning. Distance practicum requires students' independence in collecting materials, modifying tools, preparing practicum worksheets, and choosing practicum locations. The practicum stages must be arranged to create encouragement from within students to carry out the practicum process. The new way of practicum has made students aware that independence is a way of learning required in the implementation of distance learning. Practicum is known to be carried out by students independently after confirmation through interviews and reinforced by confirmation during an online presentation of the practicum results online.

\section{References}

Abdullah, H., Malago, J., \& Arafah, K. (2021). The Implementation of Physics Learning through Online Mode during Pandemic Covid-19 Using
Metacognitive Knowledge-based Materials. Jurnal Pendidikan IPA Indonesia, 10(2), 220-227. doi:https://doi.org/10.15294/jpii.v10i2.28583.

Adros, F., dan Nina, O. (2018). Analisis Penggunaan ELearning (Elena) untuk Mendukung Kualitas Layanan Perkuliahan. Economic Education Analysis Journal, 7(3), 1071-1082. https://doi.org/10.15294/eeaj.v7i3.28340.

[Indonesian]

Angelstam, P., Grodzynskyi, M., Andersson, K. et al. (2013). Measurement, Collaborative Learning and Research for Sustainable Use of Ecosystem Services: Landscape Concepts and Europe as Laboratory. AMBIO 42, 129-145. https://doi.org/10.1007/s13280-012- 0368-0.

Bungin, B. (2008). Penelitian Kualitatif, Komunikasi, Ekonomi, Kebijakan Publik, dan Ilmu Sosial Lainnya. Jakarta: Kencana Pranada Media Grup. [Indonesian]

Carrier, S.J., Tugurian, L.P. \& Thomson, M.M. (2013). Elementary Science Indoors and Out: Teachers, Time, and Testing. Res Sci Educ 43, 2059-2083. https://doi.org/10.1007/s11165012-9347-5.

Cohen, et al. (2007). Metode Penelitian dalam Pendidikan. New York. Routledge. [Indonesian]

Creswell, Jhon W. 2016. Research Design Pendekatan Kualitatif, Kuantitatif, dan Mixed. Yogyakarta: Pustaka Pelajar. [Indonesian]

Crippen, K.J., Archambault, L.M. \& Kern, C.L. (2013). The Nature of Laboratory Learning Experiences in Secondary Science Online. Res Sci Educ 43, 1029-1050. https://doi.org/10.1007/s11165-0129301-6.

Daniel, S.J. (2020). Education and the COVID-19 pandemic. Prospects 49, 91-96. https://doi.org/10.1007/s11125-020-09464-3.

Dede, T. K. (2018). Peran Matakuliah Konsep Dasar Ilmu Pengetahuan Alam Dalam Membekali Kompetensi Calon Guru Sekolah Dasar. Jurnal Ilmiah Ilmu Pendidikan Dasar, 1 (1): 62- 67. DOI: http://dx.doi.org/10.33603/.v1i1.1164. [Indonesian]

Degenkolb, L., Dippon, U., Pabst, S. et al. (2019). Transport and Retention of Differently Coated $\mathrm{CeO} 2$ Nanoparticles in Saturated Sediment Columns Under Laboratory and Near-Natural Conditions. Environ Sci Pollut Res 26, 1590515919. https://doi.org/10.1007/s11356-01904965-x.

Erduran, S. (2020). Science Education in the Era of a Pandemic. Sci E E Educ 29, 233-235. https://doi.org/10.1007/s11191-020-00122-w.

Galloway, T., Bowra, A., Butsang, T. et al. (2020). Education in uncertainty: Academic Life as 
Indigenous Health Scholars During COVID-19. Int Rev Educ. https://doi.org/10.1007/s11159020-09876-5.

Gürsoy, G. (2021). Digital Storytelling: Developing 21st Century Skills In Science Education . European Journal of Educational Research, 10(1), 97-113. https://doi.org/10.12973/eu-jer.10.1.97.

Han, HJ., Shim, KC. (2019). Development of an Engineering Design Process-Based Teaching and Learning Model for Scientifically Gifted Students at the Science Education Institute for the Gifted in South Korea. Asia Pac. Sci. Educ. 5, 13. https://doi.org/10.1186/s41029-019- 0047-6.

Hariyanti, D., Mun'im, A. H., \& Hidayat, N. (2020). Identifikasi Hambatan Mahasiswa dalam Pelaksanaan Pembelajaran Biologi Secara Daring Selama Pandemi Covid-19 di Kabupaten Jember. ALVEOLI: Jurnal Pendidikan Biologi, 1(1), 11-21. https://doi.org/10.35719/alveoli.v1i1.4.

[Indonesian]

Kang, D.Y. (2019). Past, present, and future of gifted science education in Korea: a historical perspective. Asia Pac. Sci. Educ. 5, 12. https://doi.org/10.1186/s41029-019-0045-8.

Khan, S., Krell, M. Scientific Reasoning Competencies: a Case of Preservice Teacher Education. Can. J. Sci. Math. Techn. Educ. 19, 446-464 (2019). https://doi.org/10.1007/s42330-019-00063-9

Lockee, B.B. (2020). Shifting Digital, Shifting Context: (re)Considering Teacher Professional Development for Online and Blended Learning in the COVID-19 era. Education Tech Research Dev. https://doi.org/10.1007/s11423-020-09836-8.

Melki, H., Bouzid, M. S., \& Mrayeh, M. (2020). University Supervisors' Expectations for Cooperating Teachers during a TVET Practical Traineeship in the Field of Physical Education . Journal of Technical Education and Training, 12(2), 77-86. $\quad$ Retrieved from https://publisher.uthm.edu.my/ojs/index.php/ ITET/article/view/5607.

Mila, E., \& Randi, N. (2020). Laporan Praktikum Mandiri Dalam Bentuk Video Presentasi untuk Mengembangkan Kreativitas dan Komunikasi Lisan di Masa Pandemi Covid-19. Prosiding Seminar Nasional Pendidikan FKIP, 3 (1): 328-339. Retrieved from: https://jurnal.untirta.ac.id/index.php/psnp/art icle/view/9948 [Indonesian]

Muris, P., Otgaar, H. (2020). The Process of Science: A Critical Evaluation of more than 15 Years of Research on Self-Compassion with the SelfCompassion Scale. Mindfulness 11, 1469- 1482. https://doi.org/10.1007/s12671-020-01363-0.
Permanasari, A., Rubini, B., \& Nugroho, O. (2021). STEM Education in Indonesia: Science Teachers' and Students' Perspectives. Journal of Innovation in Educational and Cultural Research, 2(1), 7-16. doi:https://doi.org/10.46843/jiecr.v2i1.24.

Purnami, W., Sarwanto, S., Suranto, S., Suyanti, R., \& Mocerino, M. (2021). Investigation of Science Technology Ecocultural Society (STEcS) Model to Enhance Eco Critical Thinking Skills. Journal of Innovation in Educational and Cultural Research, 2(2), 77-85. doi:https://doi.org/10.46843/jiecr.v2i2.40.

Purwanto. (2011). Evaluasi Hasil Belajar. Yogyakarta: Pustaka Pelajar. [Indonesian]

Rahman, M., Amarullah, R., \& Hidayah, K. (2020). Evaluasi Penerapan Model Pembelajaran ELearning pada Pelatihan Dasar Calon Pegawai Negeri Sipil. Jurnal Borneo Administrator, 16(1), 101-116.

https://doi.org/https://doi.org/10.24258/jba.v 16i1.656. [Indonesian]

Ramdani, A., Jufri, A., Gunawan, G., Fahrurrozi, M., \& Yustiqvar, M. (2021). Analysis of Students' Critical Thinking Skills in terms of Gender Using Science Teaching Materials Based on The 5E Learning Cycle Integrated with Local Wisdom. Jurnal Pendidikan IPA Indonesia, 10(2), 187-199.

doi:https://doi.org/10.15294/jpii.v10i2.29956.

Reiss, M.J. (2020). Science Education in the Light of COVID-19. Sci \& Educ 29, 1079-1092. https://doi.org/10.1007/s11191-020-00143-5.

Robinson, J.K. (2013). Project-Based Learning: Improving Student Engagement and Performance in the Laboratory. Anal Bioanal Chem 405, 7-13. https://doi.org/10.1007/s00216012- 6473-x.

Safaruddin, S., Ibrahim, N., Juhaeni, J., Harmilawati, H., \& Qadrianti, L. (2020). The Effect of ProjectBased Learning Assisted by Electronic Media on Learning Motivation and Science Process Skills. Journal of Innovation in Educational and Cultural Research, 1(1), 22-29. doi:https://doi.org/10.46843/jiecr.v1i1.5.

Saraswati., N.PA., \& Mertayasa, I.N.E. (2020). Pembelajaran Praktikum Kimia pada Masa Pandemi Covid-19; Qualitative Content Analysis Kecenderungan Pemanfaatan Teknologi Daring. Wahana Matematika dan Sains: Jurnal Matematika, Sains, dan Pembelajarannya, 14 (2): 144 - 161. http://dx.doi.org/10.23887/wms.v14i2.28297 [Indonesian]

Savitri, E., Amalia, A., Prabowo, S., Rahmadani, O., \& Kholidah, A. (2021). The Effectiveness of Real Science Mask with QR Code on Students' 
Problem-Solving Skills and Scientific Literacy. Jurnal Pendidikan IPA Indonesia, 10(2), 209-219.

doi:https://doi.org/10.15294/jpii.v10i2.29918.

Suoranta, J. (2020). Correction to: The Covid-19 World: Learning or Downfall. Postdigit Sci Educ 2, 546. https://doi.org/10.1007/s42438-020-00197-2.

Suryawati. (2018). Kompetensi Pembelajaran Praktikum Mahasiswa Pendidikan Vokasi Pertanian pada Pemanfaatan Potensi Lokal. PARTNER, 23 (1): 584-593. http://dx.doi.org/10.35726/jp.v23i1.301 [Indonesian]

Suyatman, Saputro, S., Sunarno, W., \& Sukarmin, (2021). The Implementation Of Research-Based Learning Model In The Basic Science Concepts Course In Improving Analytical Thinking Skills. European Journal of Educational Research, 10(3), 1051-1062. https://doi.org/10.12973/eujer.10.3.1051.

Tal, T., Levin-Peled, R. \& Levy, K.S. (2019). Teacher Views on Inquiry-Based Learning: the Contribution of Diverse Experiences in the Outdoor Environment. Innov Educ 1, 2. https:// doi.org/10.1186/s42862-019-0004-y.

Teräs, M., Suoranta, J., Teräs, H. et al. (2020). PostCovid-19 Education and Education Technology 'Solutionism': a Seller's Market. Postdigit Sci Educ 2, 863-878. https://doi.org/10.1007/s42438-02000164-x.

Tsinajinie, G., Kirboyun, S. \& Hong, S. (2020). An Outdoor Project-Based Learning Program: Strategic Support and the Roles of Students with Visual Impairments Interested in STEM. $J$ Sci Educ Technol. https://doi.org/10.1007/s10956020-09874-0.

Tuan, HL., Lu, YL. (2019). Science teacher education in Taiwan: past, present, and future. Asia Pac. Sci. Educ. 5, 15 https://doi.org/10.1186/s41029-019-0044-9.

Tzivinikou, S., Charitaki, G. \& Kagkara, D. (2020). Distance Education Attitudes (DEAS) During Covid-19 Crisis: Factor Structure, Reliability and Construct Validity of the Brief DEA Scale in Greek-Speaking SEND Teachers. Tech Know Learn. $\quad$ https://doi.org/10.1007/s10758-02009483-1.

Van de Pol, J., Volman, M., Oort, F. et al. (2015). The Effects of Scaffolding in the Classroom: Support Contingency and Student Independent Working Time in Relation to Student Achievement, Task Effort and Appreciation of Support. Instr Sci 43, 615-641. https://doi.org/10.1007/s11251-015$\underline{9351-z .}$
Vilsmaier U., Meyer E. (2019) Inquiry-Based Learning in Sustainability Science. In: Mieg H.A. (eds) Inquiry-Based Learning - Undergraduate Research. Springer, Cham. https://doi.org/10.1007/978-3-030-14223-0_31.

Yang, X., Zhang, M., Kong, L. et al. (2020). The Effects of Scientific Self-efficacy and Cognitive Anxiety on Science Engagement with the "QuestionObservation-Doing-Explanation" Model during School Disruption in COVID-19 Pandemic. J Sci Educ Technol. https://doi.org/10.1007/s10956020-09877-x.

Zunaidah, F.N. (2020). Implementasi Perkuliahan Daring Matakuliah Pendidikan Laboratorium IPA pada Masa Pandemi. Jurnal Pendidikan Dasar $\begin{array}{llll}\text { Nusantara, } & 6 & \text { (1): } & 103-115 .\end{array}$ https://doi.org/10.29407/jpdn.v6i1.14466 [Indonesian] 